\title{
TEACHING PRESENT PROGRESSIVE TENSE THROUGH WHOLE BRAIN METHOD TO THE EIGHT GRADE STUDENTS OF SMP NEGERI 3 PALU
}

\author{
IsmiaInafiah \\ Nurdin, \\ Ana Kuliahana \\ English Tadris Program, Faculty of Tarbiyah And Teacher Training \\ State Institute for Islamic Studies Palu \\ Email: ismiainafiah98@gmail.com
}

\begin{abstract}
This research aims to determine whether students' present progressive can be improved by using the Whole Brain Method. The participants were 20 eight grade students. The researcher had carried out research during the pandemic; the number of students was limited by the school. The research employed true experimental and need pre-test and post-test to both experimental class and control class. The population of this research is students in the grade VIII students of SMP Negeri Palu. The sample was selected by using random sampling technique. The samples are 20 students of class VIII A as the experiment class and VIII C as a control class. The research analyzed the data statistically data collection. The result of data analysis shows that the experimental class (85.5) is higher than the mean score of the control class (69). The deviation score of experimental class (17.64) is higher than of the control class (9.73). The result of tcounted (3.739) is higher than t-table (2.262). In analyzing the data, the researcher used 0.05 level of significance and the degree of freedom $(\mathrm{df}=10-2)$ it means that the hypothesis of the research was accepted. Therefore, the Whole Brain Method increase students' present progressive.
\end{abstract}

Keywords: Increasing, Present Progressive, Whole Brain Method. 


\section{Introduction}

Grammar is an important aspect in forming words and making sentences. The role of the grammar is very important in spoken and writing language. Grammar is also the important aspect of communication with other people, through grammar we can understand the meaning of the message that are spoken by the speakers.

Teaching of English is stressed on mastering the four basic skills: listening, speaking, reading, and writing. Besides, the knowledge of grammar is one of the important factors that the students should master because grammar enables the students to make statements about how to use the language. Mastering grammar should be integrated with the language skills and the language factors in order to make the students easier to understand the language during the communication. Grammar is needed even in the communicative ways, as J.B. Gunawan said,"...Even in real communicative activities, in which learners usually do not concentrate on language forms, grammar cannot be put aside."1

Structure as a language component plays an important role to support the language skills. Students can speak, and writing well if they have good competence in structure. we are included in a time where the tenses are used and in English there are 16 tenses but that usually use in daily activity is four tenses are present tense, present progressive, past tense, future tense. In this research the researcher is more interested in focusing on tenses as the topic discussed, especially present progressive.

Tenses are forms of verb in English. It may be changed based on the time and certain characteristic of the context of the

${ }^{1}$ J. B. Gunawan, "The Teaching of Grammar in CLT. Oriented Environment," Teflin Journal, volume VII, (Jogiakarta: IKIP Publisher, September 1993). 34 sentences. Tense is one of the grammar topics that are given to the Junior High School. However, students sometimes get difficulty in using grammar, especially present progressive because, they don't know well the uses and the forms of present progressive, whereas, this tense is very important for our daily interactions. For example: "I eat now ", they don't play football ", "I am study now ", "Are you study now?". The sentences must be "I am eating now ", they are not playing football", "Iam studying now", "Are you studying now?".

To make teaching learning process run well, the writer wants to propose an alternative method that is the one which is commonly known as Whole Brain Method. The writer uses Whole Brain Method to teaching because make students more engaged in class when they were emotionally involved in lessons that required students to see, say, hear and move physically.

It is supported by Biffle who expressed that WBT is one of the fastest growing, education reform movements in America. It rests upon the principle that teachers at every level share the same difficulties: students lack discipline, background knowledge and fundamental problem solving skills. From kindergarten to college, teachers face students who have difficulty with reading and writing. ${ }^{2}$

Nonetheless, our students respond to challenges, enjoy well-designed learning games, and can make, in the proper setting, astonishing educational progress. WBT method uses a very simple and effective approach to overcome this resistance. WBT method injects fun back into the classroom for both teacher and students.

${ }^{2}$ Chis Biffle, "Whole Brain Teaching for Challenging Kids.”( Yucaipa,CA Publisher, 04 March 2013 ). 1 
Based on the explanation above, the writer is interested in conducting a research about "TEACHING GRAMMAR PRESENT PROGRESSIVE TENSE THROUGH WHOLE BRAIN METHOD TO SECOND GRADE OF SMPN 3 PALU"

\section{Literature Review}

According to A. S. Hornby, "Tense is a verb form that shows time: the present/ past, etc". ${ }^{3}$ One of many parts of grammar is tense, and there are many kinds of tenses. One of them is present continuous tense, of which the writer would like discuss.

\subsection{Present Progressive Tense}

\section{a) Form of the Present Progressive Tense}

The present progressive tense is formed with a form of be (am,is,are)+the present participle (the infinitive+ing). ${ }^{4}$

The present progressive tense gives the idea that an action is in progress at the present time, and probably will continue. $^{5}$

According to Marcella Frank, "Present Progressive Tense expresses one action in the present of short duration and long duration, expresses future action, and expresses the

${ }^{3}$ A.S. Hornby, Oxford Advanced Learners Dictionary of Current English, (Oxford University Press, 1974). 891

${ }^{4} 2$ a.J. Thomson, A, V. Martinet, A Practical English Grammar, (Oxford: Oxford University Press, Fourth Edition, 1986).139

${ }^{5}$ Betty Schrampfer Azar, Understanding and Using Grammar, Second Edition, (Eaglewood Clift: Prentice Hall Regents, 1989).3 beginning, progression or end of an action." 6

\section{b) Affirmative Statement}

One of the present progressive forms is affirmative statement and to make an affirmative statement, by using this following formula: $\mathrm{S}+\mathrm{BE}$ (am,is, are) +Present Participle(ing-form) $+\mathrm{O}$

c) Negative Statement

To make a negative statement, we put not after the auxiliary be+verb+ing.

Formula:S+be+not+verb+ing

Examples: I'm not studying

\section{d) Present Progressive Tense is used} only for actions and happenings

For example:

- They are eating / it is raining etc.

Some verbs for example, know and like are not action verbs.

Incorrect: "I am knowing" or "They are liking"

Correct: "I know" or "They like"

The following verbs are not normally used in continuous tense: ${ }^{7}$

\subsection{Interrogative}

The student can also form present progressive into interrogative sentences, and there are two kinds of interrogative sentences:

\footnotetext{
${ }^{6}$ Marcella Frank, Modern English, Exercises for Non-Native Speakers, Part 1 Parts of Speech (New Jersey: Prentice Hall Regents, 1989).48

${ }^{7}$ Raymond Murphy, English Grammar in Use, A Self Study Reference Book for Intermediate Students, (Cambridge University, 1994).8
} 


\section{a) Interrogative Affirmative}

To make a negative interrogative, contractive form of be, put before the subject.

Formula:

$\mathrm{Be}+$ Subject+Verb+ing $+\mathrm{O}$

Examples: Am I doing homework?

\section{b) Negative Interrogative}

To make a negative, contractive form of be, put before the subject.

Formula: Contractive form of $\mathrm{Be}+$ Subject + Verb $+(\ldots \ldots$.

Example: Isn't $+\mathrm{He} /$ she/it + sleeping now?

Something must be noticed concerning with form of the Present continuous tense that is the process of forming the infinitive form into ing-form. Because each verb has different form, so in adding to infinitive it will undergo different process.

\subsection{Usage of Present Progressive Tense}

Based on Raymond Murphy, there are some usages of present continuous tense, as follows: ${ }^{8}$

a. The present progressive is used when expressing about something that is happening at the time of speaking :

- Please don't make so much noise. I'm studying

b. The present progressive tense also used when talking about something that is happening around the time of speaking, but not necessarily exactly at the time of speaking, study this example of situation :

\footnotetext{
${ }^{8}$ Raymond Murphy, English Grammar in Use- A self study reference and practice book for intermediate students, (New York: Cambridge University Press, 1985).2
}

Tom and Ann are talking and drinking in a café

Tora says: "I'm reading an interesting book at the moment.

I'll lend it to you when I've finished it"

Tom is not reading the book at the time of speaking. He means that he has begun the book and haven't finished it yet. $\mathrm{He}$ is in the middle of reading it.

c. The present progressive is used when talking about a period around the present for example today, this week, this season, etc.:

- "you are working hard today" "yes

I have a lot of job to do"

- Tom is not playing football this season. He wants to concentrate on his studies.

d. The present progressive is used when talking about changing situation :

- The population of the world is rising very fast (not rises)

- Is your English getting better? (not does ......... Get)

e. The present progressive when we talk about a future plan:

- He is giving a lecture tomorrow

- The ship is sailing next week

f. With always for a frequently repeated action unreasonable to the speaker :

- You are always interrupting me

- My father is always sleeping in the morning.

\subsection{Stative Verbs}

Stative verbs describe a state rather than an action. They aren't usually used in the present continuous form. 
Stative verbs (or state verbs) have the following characteristics:

1. They express a state rather than an action.

2. They refer thoughts, sense, emotions, feelings, and possessions.

3. They are not usually used in the progressive tense (i.e., with -ing).

4. Some verbs can be used as both state verbs and action verbs.

\subsection{The Meaning of Whole Brain Teaching Method}

Whole Brain Teaching was formerly known as "Power Teaching". Wong (2015:2) states, "WBT is educational reform created in 1999 by Crafton Hills College philosophy teacher Chris Biffle and elementary school teachers Jay Vanderfin and Chris Rekstad". Biffle and his college (2013) found out that students are more engaged in class when they were emotionally involved in lessons that required students to see, say, hear and move physically. Preslee, Kharasati, and Prakasha (2017:77) state, "WBT gives the freedom to the students to visualize, draw and act out their learning".

The philosophy of WBT is surrounded by seven core technique of teaching referred to as the Bib Seven (Biffle, 2010:41-45 ). ${ }^{9}$
a) Technique
1: $\quad$ Class-Yes (attentiongetter)
b) Technique 2: Classroom Rules (theorganizer)
c) Technique 3: Teach-Okay (Whole Brain Activator)

${ }^{9}$ B.S.Handayani and A.D Corebima, Model Brain Based Learning (BBL) and Whole Brain Teaching (WBT) in Learning (2017). International Journal of Science and Applied Science: Conference Series.Vol.1.153-161. d) Technique 4: Scoreboard (the motivator)

e) Technique 5: Mirror (the class unifier)

f) Technique 6: Hand and Eyes (the focuser)

g) Technique 7: Switch (the involver)

\section{Research Method}

\subsection{Method}

In this research, the researcher was used the experimental method. Experimental research is a scientific approach to research, where one or more independent variables are manipulated and applied to one or more dependent variables to measure their effect on the latter. The effect of the independent variables on the dependent variables is usually observed and recorded over some time, to aid researchers in drawing a reasonable conclusion regarding the relationship between these 2 variable types.

The experimental research method is widely used in physical and social sciences, psychology, and education. It is based on the comparison between two or more groups with a straight forward logic, which may, however, be difficult to execute.

\subsection{Design of The Research}

The researcher was used PretestPosttest Control Group Design. In this design there are two groups chosen randomly, then given a pretest to find out the initial conditions is there a difference between the experimental group and the control group.

In this study, researchers used the Pretest-Posttest Control Group Design, this is in line with the opinion of Sugiyono, (2012: 112) who stated "the design of experimental research including the Pretest- 
Posttest Control Group Design". ${ }^{10}$ By using this design the experimental group and the control group have the same characteristics because they are will take random (random) from a homogeneous population as well. In this design, the two groups were the first was gave a pre-test with the same test. Then the experimental group was gave a special treatment that is learning by using the Whole Brain Method, while the control group treat as usual by using the Conventional method. After being treated both groups in the test with the same test as the final test (post-test) the results of the two final tests were compared, as well as the results of the initial test with the final test in each group.

\subsection{Technique of Data Analysis}

To analyze the data, the writer used statistical calculation of the t-test to determine the final calculation of to that was done to measure the last score of the research test. The t-test is a kind of statistical calculation used to examine the truth or the false of null hypothesis that states no significant differences between the result of two samples from a same population. It is useful to describe and to find out the effectiveness of one method or technique used in an experiment.

\section{Table Classifying the Student Score}

\begin{tabular}{|l|l|l|}
\hline No & Category & Score \\
\hline 1 & Excellent & $81-100$ \\
\hline 2 & Good & $61-80$ \\
\hline 3 & Fair & $41-60$ \\
\hline 4 & Poor & $22-40$ \\
\hline
\end{tabular}

${ }^{10}$ Sugiyono, MetodePenelitian Pendidikan: PendekatanKuantitatif, dan R \& D, (Bandung: Alfa Beta,2008), 112.

\begin{tabular}{|l|l|l|}
\hline 5 & Very Poor & $0-21$ \\
\hline
\end{tabular}

(Source: Archive file belonging to English subject of SMPNEGERI 3 PALU ). ${ }^{11}$

To determine in induvial score, the researcher was analyzed the students standard score in the pre-test and post-test by using the following formula.

$$
\frac{A}{N} \times 100
$$

Where: $\mathrm{A}=$ the number of students who answered the item correctly

$\mathrm{N}=$ the total number of students who attend the item

$100=$ constant number ${ }^{12}$

Then, the researcher was analyzed the mean of the groups on pre-test and posttest using the formula purposed by Hatch and Farhady (1982:55):

$$
x=\frac{\sum x}{N}
$$

Where:

$$
\begin{array}{ll}
\mathrm{X} & =\text { mean score } \\
\sum x & =\text { the sum of all score } \\
\mathrm{N} & =\text { the total number of samples }
\end{array}
$$

Calculating the standard deviation of students, the researcher applied the following formula:

\footnotetext{
${ }^{11}$ Departemen Pendidikan Nasional. PetunujukPengajaran Bahasa Inggris ( Jakarta:Depniknas, 2003)

${ }^{12}$ SuharismiArikunto, Dasar-Dasar Evaluasi Pendidikan (EdisiRevisi). (Jakarta: PT Bumi Aksara.2009), 245

${ }^{13}$ Sukardi, Methodology Penelitian Pendidikan Kompetensi dan Praktiknya, ( Jakarta: PT. Bumi Aksara,2004), 88
} 


$$
\begin{aligned}
S D=\sqrt{\frac{S S}{N}}-1 \text { wheres } S & \\
& =\sum_{x} 2-\left(\sum_{x}\right) \frac{2}{N}
\end{aligned}
$$

Where:

SD $=$ the standard derivation.

$\mathrm{SS}=$ the square root of the sum of squares.

$\sum_{x} \quad=$ the sum of square

$\mathrm{N}=$ the total number of students ${ }^{14}$

Finding the difference of mean score between pre-test and post-test by calculating the value of the test, applying for non independent sample t-test formulating:

$t=\frac{x 1-x 2}{\sqrt{\left(\frac{s s 1+s s 2}{N 1+N 2-2}\right)\left(\frac{1}{N 1}+\frac{1}{N 2}\right)}}$

Where:

$\mathrm{t}=$ test of significance

$\mathrm{X}_{1} \quad=$ mean score of experimental class

$\mathrm{X}_{2} \quad=$ mean score of control class.

$\mathrm{SS}_{1}=$ the sum square of experimental class

$\mathrm{SS}_{2}=$ the sum of control class

$\mathrm{N}_{1} \quad=$ the total number of experimental class

$\mathrm{N}_{2} \quad=$ the total number of control class

\section{Result and Discussion}

\subsection{Finding of Result}

To know the result of the test, the writer presents both the sample of pre-test

${ }^{14}$ L.R Gay, Geoffrey, Peter , Education Research Comptencis for Analysis and Application,Eight Edition,(New Jersey: Pearson Merril Prentice Hall,2006), 321 and post-test, and has made the table of students scores of the pre-test and post-test, and table of its comparison as well.

\subsection{Finding of Pre-test}

Before giving the treatment, the researcher administered a pre-test ability of the VIII Grade students of SMPN 3 Palu in Present Progressive. The researcher computed the result score of the pre-test as can be seen in the following table

a) Result of Pre-test of the Experimental class

After calculating the total score, the researcher analyzed the mean score of pre-tests of the experimental class by using formula:

$x=\frac{\sum x}{N}$

$x=\frac{575}{10}$

$\boldsymbol{x}=\mathbf{5 7 . 5}$

Based on the analysis, it can be seen that the mean score of pre-tests of experimental class was 57.5

b) Result of pre-test of the control class

After calculating the total score, the researcher analyzed the mean score of pre-tests of the experimental class by using formula:

$$
x=\frac{\sum x}{N}
$$

$$
x=\frac{600}{10}
$$

$$
x=60
$$


Based on the analysis, it can be seen that the mean score of post-tests of experimental class was 60 .

Based on the second table above, it is clear that the lowest score of pre-test Experimental Class is 57.5 and the highest score of post-test Control Class is 60 which indicates that the pre-test Experimental Class scores are higher than the pre-test Control Class score.

\subsection{Finding of Post-test}

After giving the treatment, the researcher administrated post-test. The result of the post-test is presented as follows:

a) Result of Post-test of the Experimental class

After calculating the total score, the researcher analyzed the mean score of post-tests of the experimental class byusing formula:

$x=\frac{\sum x}{N}$

$x=\frac{855}{10}$

$x=85.5$

Based on the analysis, it can be seen that the mean score of post-tests of experimental class was 85.5

\section{b) Result of post-pest of the control class}

After calculating the total score, the researcher analyzed the mean score of pre-tests of the experimental class byusing formula:

$$
x=\frac{\sum x}{N}
$$

$$
\begin{gathered}
x=\frac{690}{10} \\
x=69
\end{gathered}
$$

Based on the second table above, it is clear that the lowest score of posttest Control Class is 69 and the highest score of post-test Experimental Class is 85.5 which indicates that the post-test Control Class scores are higher than the posttest Experimental Class score.

c) Deviation and square deviation of experimental class

$$
\begin{aligned}
& M_{y}=\frac{285}{10} \\
& M_{y}=28.5
\end{aligned}
$$

$$
\begin{aligned}
S=\sqrt{\frac{S S}{N}}-1 \text { where } S S & \\
& =\sum X^{2}-\frac{\left(\sum X\right)^{2}}{N} \\
S S & =10925-\frac{(285)^{2}}{10} \\
S S & =10925-\frac{81.225}{10} \\
S S & =10925-8.122 .5 \\
S S & =2802.5
\end{aligned}
$$

$\mathrm{SO}_{1}$

$S D=\sqrt{\frac{S S}{N}}-1$ 


$$
\begin{aligned}
& S D=\sqrt{\frac{2802.5}{10}}-1 \\
& S D=\sqrt{\frac{2802.5}{9}} \\
& S D=\sqrt{311.388} \\
& S D=17.64
\end{aligned}
$$

d) Deviation and square deviation of controlled class

Control Class:

$$
\begin{aligned}
& M_{x}=\frac{165}{10} \\
& M_{x}=16.5
\end{aligned}
$$

$$
\begin{aligned}
& S D=\sqrt{\frac{S S}{N}-1 \text { whereSS }} \\
&=\sum X^{2}-\frac{\left(\sum X\right)^{2}}{N} \\
& S S=3.575-\frac{(165)^{2}}{10} \\
& S S=3.575-\frac{27.225}{10} \\
& S S=3.575-2.722 .5
\end{aligned}
$$$$
S S=85.25
$$$$
\mathrm{SO}_{1}
$$

$$
S D=\sqrt{\frac{S S}{N}}-1
$$

$$
S D=\sqrt{\frac{85.25}{10}}-1
$$

$S D=\sqrt{\frac{85.25}{9}}$

$$
S D=\sqrt{94.72}
$$

$S D=9.73$

The different of mean score between pre-test and post-test by calculating the value of the test applying for nonindependent sample t-test formulating:

$$
\begin{gathered}
t=\frac{M_{x}-M_{y}}{\sqrt{\left(\frac{S S_{1}+S S_{2}}{N_{1}+N_{2}-2}\right)\left(\frac{1}{N_{1}}+\frac{1}{N_{1}}\right)}} \\
t=\frac{16.5-28.5}{\sqrt{\left(\frac{2802.5+85.25}{10+10-2}\right)\left(\frac{1}{10}+\frac{1}{10}\right)}} \\
t=\frac{-12}{\sqrt{\left(\frac{2.887 .75}{18}\right)\left(\frac{2}{10}\right)}} \\
t=\frac{-12}{\sqrt{(160.43)(0.2)}} \\
t=\frac{-12}{32.086} \\
t=3.739
\end{gathered}
$$

$t$-counted was 3.739 


\section{e) Hypothesis Testing}

The hypothesis of the research was to find out whether or not used Whole Brain Method is effective to improve students Present Progressive at eighth grade of SMP NEGERI 3 Palu. To the hypothesis, the researcher used two-failed test, with 0.05 and 0.01 of significance and the degree of freedom based on the following formula:

$$
\text { Df } \quad \begin{aligned}
=\mathrm{N}-2 \\
=10-2 \\
=8
\end{aligned}
$$

Based on the table $\mathrm{d} f 8$, significance level of $5 \%$ and $1 \%$ are:

$\mathrm{t}$ table at significance levelof $5 \%=2.262$

$\mathrm{t}$ table at significance level of $1 \%=2.821$

it means that $\mathrm{t}_{0}$ ( $\mathrm{t}$ observation) is bigger than $\mathrm{t}_{\mathrm{t}}(\mathrm{t}$ table)

Before deciding the result of hypothesis, the writer proposed interpretation toward $t_{0}$ ( $t$ observation) with procedure as follows:

a. Formulating alternative hypothesis (Ha); there are significant mean differences between variable $\mathrm{X}$ and $\mathrm{Y}$.

b. Formulating null hypothesis (Ho): there are significant mean differences between variable $\mathrm{X}$ andY.

Furthermore, the writer has the criteria to test the hypothesis as follows:

a. If the result of calculation $t_{o}(t$ observation) is higher than $t_{t}(t$ table), $\mathrm{t}_{\mathrm{o}}>\mathrm{t}_{\mathrm{t}}$ : the null hypothesis (Ho) is rejected. It means that there are significant differences between variable $\mathrm{X}$ and $\mathrm{Y}$.

b. If the result of calculation $t_{0}(t$ observation) is lower than $t_{t}(t$ table), $t_{0}>t_{0}$ : the null hypothesis
(Ho) is accepted. It means that there are significant differences between variable $\mathrm{X}$ and $\mathrm{Y}$.

Based on the result of the calculation, the writer obtained value of $t_{0}$ 3.739 and degree of freedom $(\mathrm{df})=8$

To know whether it is significant or not, it is better to look at the t table in appendix. The result of tt on significant $5 \%$ $=2.262$ and $1 \%=2.821$. it indicates that $\mathrm{t}_{\mathrm{o}}>\mathrm{t}_{\mathrm{t}}$ or $3.739>2.821$ or $(2.262<3.739>$ 2.821 ), so the zero hypothesis is rejected and the alternative hypothesis is accepted. It means that there is a significant affective of applying WBT method in teaching Present Progressive in improving students achievement.

\section{Conclusion and Suggestion}

\subsection{Conclusion}

From the calculation in the previous chapter stated that the value of to is higher than $t_{t}$, it means that $t_{0}=3.379$ indicate that there is a significant difference between the result of learning present progressive by using Whole Brain Method and without using Whole Brain Method.

The writer concludes that the students' post-test scores in present progressive taught by using Whole Brain Method are higher than the student's posttest score that taught without using Whole Brain Method. This method solves the difficulties that happened that most of students did not know the correct present progressive.

So, using Whole Brain Method is an alternative way to help students to understand better in studying present progressive.

The student could improve their scores of present progressive taught by using 
Whole Brain Method. So, by using Whole Brain Method in teaching present progressive will be easy to understanding.

\subsection{Suggestion}

The writer would like to give some suggestion that might be useful for the readers, students and the English teacher:

1. Selecting the appropriate method in learning is very important, because each method has the advantages and disadvantages.

2. Teaching present progressive by using Whole Brain Method will be more useful for all of the students.

3. To make the students more enthusiastically, it is better to use the Whole Brain Method.

4. The students are more practice and to improve their English grammar especially in present progressive taught by using Whole Brain Method as an alternative way to express their imagination and to get more ideas and information.

5. It is necessary to do more exercises in learning present progressive in order to improve student English grammar of Present Progressive. 


\section{References}

ArikuntoSuharismi, Dasar-Dasar Evaluasi Pendidikan (Edisi Revisi). Jakarta: PT BumiAksara, 2009.

Bowen, Morgan Betty and Look, Herel. Visual Aids in Language Teaching, London: Essential Language Teaching Series, 1973.

Biffle Chis, Whole Brain Teaching for Challenging Kids. Yucaipa, CA Publisher, 04 March 2013

Celce, Marianne and Hills, Sharon. Technique and Resources in Teaching Grammar, New York: Oxford University Press, 1998.

Departemen Pendidikan Nasional. Petunujuk Pengajaran Bahasa Inggris, Jakarta:Depniknas, 2003.

Edge, Julian. Essentials of English Language Teaching: 3rd Edition, London: Longman, 2003.

Edmundo, Mora J. "Using Pictures Creatively". English Teaching Forum, Vol XXVI, Washington DC: Forum, October: 1988.

Frank, Marcella. Modern English, ExercisesForNon-Native Speakers, Part 1 Parts of Speech New Jersey: Prentice Hall Regents, 1989.

Gunawan, J. B. "The Teaching of Grammar in CLT. Oriented Environment," Teflin Journal, volume VII, Jogjakarta: IKIP Publisher, September 1993.

Gay L.R, Geoffrey, Peter, Education Research Competencies for Analysis and Application, Eight
Edition, New Jersey: Pearson Merrill Prentice Hall, 2006.

Hornby, A.S. Oxford Advanced Learner's Dictionary of Current English, Oxford: Oxford University Press, 2000.

Handayani, B.S. and Corebima, A.D. Model Brain Based Learning (BBL) and Whole Brain Teaching (WBT) in Learning. International Journal of Science and Applied Science: Conference Series.Vol.1.153-161, 2017.

Murphy, Raymond. English Grammar in Use, A Self Study Reference Book for Intermediate Students, Cambridge University, 1994.

Roszkowski, A. J. The Selection and Use of Instructional Media: for Improved Classroom Teaching and Interactive, Individualized Instruction, London: Kogen, 1988.

Schrampfer, Azar Betty. Understanding and Using Grammar, Second Edition, Eaglewood Clift: Prentice Hall Regents, 1989.

Sukardi, Methodology Penelitian Pendidikan Kompetensi dan Praktiknya, Jakarta: PT. Bumi Aksara,2004

Thomsong, a.J, A, V. Martinet, A Practical English Grammar, Oxford: Oxford University Press, Fourth Edition, 1986.

Wright, Andrew. Pictures for Language Learning, Cambridge: Cambridge University Press, 1989. 